\title{
Localization and Function of a 5-HT Transporter in Crypt Epithelia of the Gastrointestinal Tract
}

\author{
P. R. Wade, ${ }^{1}$ J. Chen, ${ }^{1}$ B. Jaffe, ${ }^{2}$ I. S. Kassem, ${ }^{1}$ R. D. Blakely, ${ }^{3}$ and M. D. Gershon ${ }^{1}$ \\ ${ }^{1}$ Department of Anatomy and Cell Biology, College of Physicians and Surgeons, Columbia University, New York, New \\ York 10032, ${ }^{2}$ Department of Surgery, Tulane University School of Medicine, New Orleans, Louisiana 70112-2699, and \\ ${ }^{3}$ Department of Pharmacology, Vanderbilt University School of Medicine, Nashville, Tennessee 37232-6600
}

\begin{abstract}
The peristaltic reflex can be evoked in the absence of input from the CNS because the responsible neural pathways are intrinsic to the intestine. Mucosal enterochromaffin cells have been postulated to be pressure transducers, which activate the intrinsic sensory neurons that initiate the reflex by secreting $5-\mathrm{HT}$. All of the criteria necessary to establish $5-\mathrm{HT}$ as this transmitter have been fulfilled previously, except that no mucosal mechanism for 5-HT inactivation was known. In the current investigation, desensitization of 5-HT receptors was demonstrated to inhibit the peristaltic reflex in the guinea pig large intestine in vitro. At low concentration (1.0 nM), the 5-HT uptake inhibitor fluoxetine potentiated the reflex, but higher concentrations blocked it, suggesting that the peristaltic reflex depends on the 5-HT transporter-mediated inactivation of 5-HT.
\end{abstract}

Specific $\left(\mathrm{Na}^{+}\right.$-dependent, fluoxetine-sensitive) uptake of ${ }^{3} \mathrm{H}$ $5-\mathrm{HT}$ by intestinal crypt epithelial cells was found by radioautography. mRNA encoding the neuronal $5-\mathrm{HT}$ transporter was demonstrated in the intestinal mucosa by Northern analysis and located in crypt epithelial cells as well as in myenteric neurons by in situ hybridization. cDNA encoding the 5- $\mathrm{HT}$ transporter was cloned from the mucosa and completely sequenced. 5-HT transporter immunoreactivity was detected in crypt epithelial cells and enteric neurons. Mucosal epithelial cells thus express a plasmalemmal 5-HT transporter identical to that of serotonergic neurons. This molecule seems to play a critical role in the peristaltic reflex.

Key words: enterochromaffin cell; 5-HT $T_{1 P}$ receptor; 5-HT receptor; fluoxetine; enteric norvous system; colon; motility
The enteric nervous system (ENS) is the only region of the peripheral nervous system that contains complete reflex circuits (Gershon et al., 1994; Furness et al., 1995). Intrinsically mediated reflexes such as the peristaltic thus can be elicited in isolated segments of gut (Trendelenburg, 1917). Considerable evidence supports the idea that mechanosensitive mucosal receptors, which initiate the peristaltic reflex, are 5-HT-containing enterochromaffin (EC) cells (Erspamer, 1954; Bülbring et al., 1958; Bülbring and Crema, 1959a,b; Kosterlitz and Lees, 1964). In response to pressure (Bülbring and Crema, 1959b), these cells secrete 5-H'I' into the lamina propria (Toh, 1954; Nilsson et al., 1987), where subepithelial nerve fibers express 5-HT receptors (Branchck ct al., 1984a,b; Wade ct al., 1994) and are excited by 5-HT (Bülbring and Lin, 1958; Feng et al., 1994). Excitation of submucosal sensory neurons in response to mucosal pressure is blocked by $5-\mathrm{HT}_{1 \mathrm{P}}$ (Kirchgessner et al., 1992) or 5-HT 4 (FoxxOrenstein et al., 1995) antagonists. 5-HT-sensitive submucosal sensory neurons project to the myenteric plexus, where the peristaltic reflex is integrated (Smith et al., 1990; Grider, 1994; Grider and Jin, 1994). 5-HT, therefore, seems to play a critical role in initiating the peristaltic reflex.

If 5-HT is an EC cell to sensory neuron transmitter, a means of inactivating intramucosal 5-HT would be predicted. The action of transmitters is characteristically limited temporally and spatially;

Received Nov. 7, 1995; revised Jan. 2, 1996; accepted Jan. 4, 1996.

This work was supported by National Institutes of Health Grants NS12969 and NS15547 (M.D.G.), and DA07390 (R.D.B.) and by the Glaxo Research Institute (P.R.W.). We thank Ms. Diane Sherman for her expert technical advice and for the whole-mount radioautography.

Correspondence should be addressed to Dr. Paul R. Wade, Department of Anatomy and Cell Biology, Columbia University (P\&S 12-513), 630 West 168th Strect, New York, NY 10032.

Copyright 1996 Society for Neuroscience $0270-6474 / 96 / 162352-13 \$ 05.00 / 0$ moreover, enteric 5-HT receptors are subject to desensitization (Gershon and Wade, 1994). If 5-HT were to accumulate, therefore, 5-HT receptors on sensory nerves would be expected to desensitize. A mucosal mechanism for 5-HT inactivation has not been identified previously. Serotonergic neurons inactivate 5-HT by reuptake (Brownstein and Hoffman, 1994) mediated by a specific 5-HT transporter, which has been cloned and sequenced (Blakely et al., 1991; Hoffman et al., 1991). There are, however, no serotonergic nerves in the mucosa (Costa et al., 1982; Furness and Costa, 1982), and 5-HT is not taken up by mucosal nerve fibers (Gershon and Sherman, 1982). Monoamine oxidase in the intestinal epithelium (Baldessarini, 1990; Gershon et al., 1990) is intracellular and thus should not affect extracellular 5-HT. 5-HT is absorbed into the portal circulation (Toh, 1954; Ahlman et al., 1978), which could help to reduce its effective concentration; nevertheless, this mechanism is probably too slow to inactivate a transmitter. Non-neuronal cells such as platelets (Rudnick, 1977; Williams and Phillips, 1991) and mast cells (Hoffman et al., 1991) take up 5-HT. The current study was undertaken to determine whether a non-neuronal element of the intestinal mucosa expresses the 5-HT transporter, to locate it, and to ascertain its importance in the peristaltic reflex. Observations support the ideas that 5-HT initiates the peristaltic reflex, that crypt epithelial cells express the same 5-HT transporter that is expressed by serotonergic neurons, and that the 5-HT transporter plays an important role in terminating the mucosal action of 5-HT.

\section{MATERIALS AND METHODS}

Colonic motility. Segments $(\sim 8 \mathrm{~cm}$ long) of guinea pig distal colon were secured to the bottom of a Sylgard-lined (Dow Corning, Midland, MI) organ bath $(40 \mathrm{ml})$ with pins placed through a small flap of attached mesentery. The preparations were perfused continuously with oxygenated 


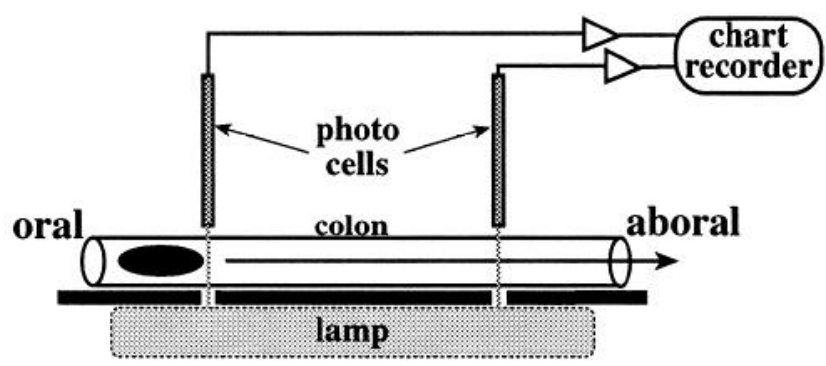

Figure 1. Reflex-initiated propulsion of artificial fecal pellet by the guinea pig distal colon was detected in a specialized chamber that permitted motility to be measured photometrically. The bottom of the organ bath was opaque, except for two slits $5 \mathrm{~cm}$ apart. The organ bath was positioned over a light box, and the peristaltic reflex was evoked by inserting the pellet into the oral opening. When the opaque pellet passed over the slits, the change in light level was sensed by a photocell. Output from oral and anal photocells was directed to a flatbed recorder. The rate of propulsion was proportional to the distance between pen deflections.

Krebs solution and thermostatically maintained at $35^{\circ} \mathrm{C}\left( \pm 1^{\circ}\right)$. The peristaltic reflex was evoked by inserting solid pellets into the oral end of the isolated segments of bowel (Costa and Furness, 1976). These pellets were fashioned from a silicone elastomer (Sylgard) and were about the same size, shape, and weight as a fecal pellet. The pellets were transported distally from their point of insertion. The rate at which the pellet moved was measured manually by direct observation or automatically by determining the time taken by the pellet to traverse the distance between two light-sensitive probes (Fig. 1).

Preparations were allowed to equilibrate for $30 \mathrm{~min}$ before the experiments were begun. A baseline rate of motility was then determined for each preparation by averaging the rate of propulsion measured for three to five consecutive trials at $5 \mathrm{~min}$ intervals. Each trial consisted of one complete passage of the pellet down the entire length of the segment of colon. The pellet was retrieved and reinserted at the oral end at the conclusion of each passage. Experimental compounds were added after the control records were obtained. The colon was incubated for $15 \mathrm{~min}$ in the presence of the compound before resuming measurement of the rate of propulsion of the pellets. For each compound, the peristaltic reflex was again quantified by averaging the rate of propulsion measured for three to five consecutive trials at $5 \mathrm{~min}$ intervals. Preparations were then washed with three to five complete changes of Krebs solution and allowed to equilibrate for $15 \mathrm{~min}$, and the recovery of the peristaltic reflex was determined once more by averaging the rate of propulsion measured for three to five consecutive trials at $5 \mathrm{~min}$ intervals. The rate of propulsion of the pellet in the presence of test compounds was expressed as a percentage of the control rate determined for the same segment of colon. Each preparation thus served as its own control, and each served as a single value for comparisons between treatments. Comparisons between means for different compounds and/or different concentrations of a single compound were analyzed by using the Scheffé F-test. Differences were considered to be significant if the value determined for $p$ was $<0.05$. The specificity of the action of fluoxetine on the peristaltic reflex was tested by measuring the responsiveness of colonic segments to acetylcholine $(\mathrm{ACh})$, nicotine, or transmural electrical stimulation $(0.5 \mathrm{msec}, 150 \mathrm{~V}, 1$ $\sec$ at $10 \mathrm{~Hz}$ ). The preparations were attached at the distal end to a force transducer (FORT10, World Precision Instruments, Sarasota, FL), the output of which was amplified and directed to a flatbed chart recorder (Kipp and Zonen, Bohemia, NY). The resting tension of the preparations was adjusted to $0.5 \mathrm{gm}$ and allowed to equilibrate at this level for $30 \mathrm{~min}$ before stimulation. In each of these experiments, data were collected as the average of three consecutive stimuli (controls), three stimuli in the presence of fluoxetine $(1.0$ or $10.0 \mu \mathrm{M})$, and three stimuli after the washout of fluoxetine. Data were expressed as a percentage of the control contraction, and differences between control and washout values were determined using Student's $t$ test. Differences were considered to be significant if the value determined for $p$ was $<0.05$.

Radioautographic visualization of sites of ${ }^{3} \mathrm{H}-5-\mathrm{HT}$ uptake. Segments of rat and guinea pig small intestine and distal colon ( $2 \mathrm{~cm}$ in length) were opened along the mesenteric border and cut into full-thickness flat sheets of tissue. These sheets were pinned along their edges to a frame made of Sylgard. The frames were weighted at one end with a small stainless steel clip, which enabled the preparations to be immersed in solutions. The opened sheets of bowel fastened to the frames (which served as holders) were then incubated at $35^{\circ} \mathrm{C}$ in Krebs solution (gassed with a mixture of

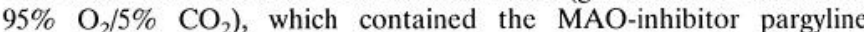
$(10 \mu \mathrm{M})$. Tissues were equilibrated in this solution for $15 \mathrm{~min}$, after which ${ }^{3} \mathrm{H}-5-\mathrm{HT}(0.1 \mu \mathrm{M}$ in Krebs) was added, and incubation was continued for an additional $45 \mathrm{~min}$. Specificity controls included the addition of fluoxetine $(1.0 \mu \mathrm{M})$ or substitution of choline chloride for $\mathrm{NaCl}$ in the Krebs solution. After incubation, tissues were washed with iced Krebs solution and fixed for $4 \mathrm{hr}$ in $4 \%$ formaldehyde (from paraformaldehyde) in $0.1 \mathrm{M}$ phosphate buffer containing 3\% sucrose (Gershon and Ross, 1966). Fixed tissues were removed from their frames, rinsed with PBS, cryoprotected by overnight incubation in PBS containing 30\% sucrose, embedded in O.C.T. (Miles, Elkhart, IN), and sectioned at $10-15 \mu \mathrm{m}$ in a cryostatmicrotome. Sections were thaw-mounted onto gelatin-coated glass slides, air-dried, dehydrated in graded alcohols, cleared in xylene, and passed through a mixture of xylene/ether (1:1) and $100 \%$ ether before drying in air (Gershon et al., 1990). The defatted dried slides were dipped in liquid radiographic emulsion (Ilford L4, Polysciences, Warrington, PA). The slides were exposed for $1-2$ weeks at $4^{\circ} \mathrm{C}$ (over silica gel). Exposed slides were developed with Kodak D-19, fixed, and washed in water. The tissues were then stained with toluidine blue, and coverslips were permanently mounted. The sections were examined and photographed using vertical dark-field illumination.

Northern analysis. The edge of a glass slide was used to remove the mucosa from the surface of opened segments of small intestine. The brainstem was also dissected from adult rats and guinea pigs to serve as a positive control. Total RNA was extracted from each tissue by the acid guanidinium thiocyanate-phenol-chloroform method (Chomczynski and Sacchi, 1987). Total RNA ( $25 \mu \mathrm{g})$ was resolved by electrophoresis on a $0.9 \%$ agarose gel under denaturing conditions and transferred to a Duralon-UV membrane (Stratagene, La Jolla, CA). The full-length cDNA encoding the rat brain 5-HT transporter (Blakely et al., 1991, 1993) was excised from pBluescript $\mathrm{SKII}^{-}$(Stratagene) with NotI and $X h o I$ and used to synthesize $\left[{ }^{32} \mathrm{P}\right]$-labeled cDNA with $\alpha-\left[{ }^{32} \mathrm{P}\right]-\mathrm{dCTP}$ by using a random priming kit (Promega, Madison, WI). Blots were prehybridized at $42^{\circ} \mathrm{C}$ in a solution containing $50 \%$ formamide, $5 \times$ SSPE, $5 \times$ Denhardt's solution, $10 \%$ dextran sulfate, $1 \%$ SDS, and $100 \mu \mathrm{g} / \mathrm{ml}$ salmon sperm DNA for 3-4 hr. The [ $\left.{ }^{32} \mathrm{P}\right]$-labeled cDNA probe was then added, and hybridization was continued overnight. The blots were rinsed (two times for $15 \mathrm{~min}$ each time, room temperature) in a solution containing $2 \times \mathrm{SSPE}$ and $0.1 \%$ SDS, followed by a rinse for $1 \mathrm{hr}$ at $60^{\circ} \mathrm{C}$ in a solution containing $0.1 \times$ SSPE and $0.1 \%$ SDS. Blots were then exposed with an intensifying screen for $6 \mathrm{~d}$ to Kodak X-OMAT film.

In situ hybridization. Cells containing mRNA encoding the 5-HT transporter were localized by in situ hybridization. Animals were perfused intracardially with saline, followed by perfusion for 5-10 min with $4 \%$ formaldehyde (freshly prepared from paraformaldehyde) in $0.1 \mathrm{M}$ PBS, $\mathrm{pH} 7.5$. Tissues were then removed from the animal and postfixed with the same fixative for an additional $4 \mathrm{hr}$ at room temperature or $12 \mathrm{hr}$ at $4^{\circ} \mathrm{C}$. Tissues to be sectioned were rinsed in PBS and then immersed in $30 \%$ sucrose $(\mathrm{w} / \mathrm{v})$ in PBS overnight at $4^{\circ} \mathrm{C}$. The tissues were then embedded in O.C.T. and stored at $-80^{\circ} \mathrm{C}$. Sections $(10-15 \mu \mathrm{m})$ were cut with a cryostat-microtome and thaw-mounted onto 3-aminopropyltriethoxysilane-coated glass slides. A full length cDNA clone encoding the rat neuronal 5-HT transporter [rSERT; (Blakely et al., 1991)] was used to synthesize ${ }^{35}$ S-UTP-labeled cRNA probes in the antisense or sense (control) orientation. These probes were used for in situ hybridization.

For in situ hybridization with radioactive probes, sections were removed from the freezer and postfixed with $4 \%$ formaldehyde (freshly prepared from paraformaldehyde). Preparations were acetylated with 0.1 $\mathrm{M}$ acetic anhydride and washed in $0.2 \times \mathrm{SSC}$. Tissues were prehybridized for $2 \mathrm{hr}$ at room temperature in a mixture containing $50 \%$ formamide, $600 \mathrm{~mm} \mathrm{NaCl}, 10 \mathrm{~mm}$ Tris, $\mathrm{pH} 7.5,1 \times$ Denhardt's reagent, $1.0 \mathrm{~mm}$ EDTA, $0.05 \%$ sheared DNA, $0.05 \%$ yeast total RNA, and $0.005 \%$ yeast tRNA. They were then hybridized at $50^{\circ} \mathrm{C}$ for $16-18 \mathrm{hr}$ in the presence of

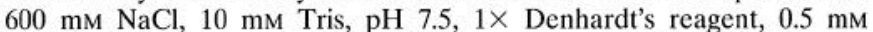
EDTA, $0.01 \%$ sheared DNA, $0.05 \%$ yeast total RNA, $0.005 \%$ yeast tRNA, $10 \%$ dextran sulfate, $10 \mathrm{~mm}$ dithiothreitol, and $0.1 \%$ SDS. Heatdenatured probes $\left(5 \times 10^{5} \mathrm{cpm}\right.$ per section) were added to the hybridization solution. After hybridization, the sections were washed first for 30 $\min$ in $50 \%$ formamide, $1 \times \mathrm{SSC}$, and $10 \mathrm{~mm}$ dithiothreitol at $50^{\circ} \mathrm{C}$ and then for $30 \mathrm{~min}$ with $0.5 \times \mathrm{SSC}$ at room temperature. The washed sections were treated with $0.1 \mathrm{mg} / \mathrm{ml} \mathrm{RNase}$ at room temperature to hydrolyze single-stranded RNA. After washing with $500 \mathrm{~mm} \mathrm{NaCl}, 10 \mathrm{~mm}$ Tris, $\mathrm{pH}$ 7.5 , and $1.0 \mathrm{~mm}$ EDTA, the slides were washed for $2 \mathrm{hr}$ at $55^{\circ} \mathrm{C}$ in $0.2 \times$ 
SSC. Sections were dehydrated in the presence of ammonium acetate $(0.3 \mathrm{M})$ and coated with liquid photographic cmulsion (Kodak NTB2) for radioautography. Slides were exposed in dry, light-tight boxes at $4^{\circ} \mathrm{C}$ and developed with Kodak D19. Processed sections were stained with hematoxylin and eosin and visualized by using indirect dark-field optics.

Because sections of bowel pass through only a small number of ganglia per section and thus sample very few neurons in any one slide, whole mounts rather than sections were used to locate neurons containing mRNA encoding the 5-HT transporter in the myenteric plexus. For this purpose, in situ hybridization was carried out with laminar preparations of longitudinal muscle with adherent myenteric plexus (LMMP) dissected from the gut wall (Wade et al., 1994). These preparations were fixed in a flat orientation and processed for in situ hybridization with the myenteric plexus facing up. Methods used for whole-mount in situ hybridization were similar to those described previously (Harland, 1991). Digoxigeninlabcled probes were prepared in the antisense and sense (control) orientations by using the Genius kit (Boehringer Mannheim, Indianapolis, IN) according to the directions of the manufacturer. Hybridizing probes were detected immunocytochemically with monoclonal antibodies to digoxigenin in association with secondary antibodies coupled to alkaline phosphatase in the presence of levamisol to inactivate endogenous alkaline phosphatase in enteric neurons (1.0 mM) (Gershon et al., 1990; Kirchgessner et al., 1990).

Cloning and sequencing of the rat mucosal 5-HT transporter. Total RNA, extracted from the gut as described above, was incubated with Maloney Murine Leukemia Virus reverse transcriptase with random hexamers. The resulting cDNAs were amplitied by PCR using a 19-bp sense primer (5'-GGGAATCCGCATCACTTAC-3') and an 18-bp antisense primer $\left(5^{\prime}\right.$-AAGAGGTGTCCTCTCCCA- $\left.3^{\prime}\right)$. These primers were designed from the known sequence of the cDNA encoding the rat neuronal 5-HT transporter (Blakely et al., 1991) and flank the translated region of the open reading frame. The sense primer corresponds to nucleotides $86-$ 104, and the antisense primer corresponds to nucleotides 2017-2034. After an initial incubation for $3 \mathrm{~min}$ at $94^{\circ} \mathrm{C}$, PCR mixtures were subjected to 30 of the following cycles: $1 \mathrm{~min}$ at $94^{\circ} \mathrm{C}, 1 \mathrm{~min}$ at $55^{\circ} \mathrm{C}$, and 2 min at $72^{\circ} \mathrm{C}$. Analysis of the amplified products on an agarose gel showed a DNA fragment of the expected size of $\sim 2 \mathrm{~kb}$. This $\mathrm{PCR}$ product was subcloned into the TA Cloning vector pCR II (Invitrogen, San Diego, $\mathrm{CA}$ ), according to the manufacturer's instructions, and double strandsequenced by the dideoxynucleotide chain termination using Scquenase 2.0 (United States Biochemical, Cleveland, $\mathrm{OH}$ )

Immunocytochemistry. Frozen sections and whole mounts of LMMP were obtained from rat and guinea pig intestine as described above. Primary antisera, directed against a 34 amino acid sequence of the intracellular carboxyl terminus of the 5-HT transporter (Qian et al., 1995) and diluted $(0.4 \mu \mathrm{g} / \mathrm{ml})$ in $0.1 \mathrm{M}$ phosphate buffer containing normal horse scrum $(4 \% \mathrm{v} / \mathrm{v})$ and Triton X-100 $(0.3 \% \mathrm{v} / \mathrm{v})$, were applied to tissues overnight at room temperature. Tissues were rinsed in buffer and then incubated for $4 \mathrm{hr}$ at room temperature with goat anti-rabbit IgG coupled to tetramethylrhodamine isothiocyanate (TRITC) diluted 1:100 (Kirkegaard and Perry, Gaithersburg, MD). For double-label immunocytochemistry, the same tissues were incubated with a mouse monoclonal antibody to 5-HT (1:50; DAKO A/S, Glostrup, Denmark), which was visualized with an affinity-purified goat anti-mouse secondary antibody coupled to fluorescein isothiocyanate (FITC) diluted 1:100 (Kirkegaard and Perry). Controls for double-label experiments included omission of one or both primary antibodies in preparations immunostained with each or both of the secondary antibodies. Sites of immunoreactivity were visualized by vertical fluorescence microscopy using a Leitz " $L_{2}$ " filter cube (exciting filter bandpass $450-490 \mathrm{~nm}$, dichroic mirror reflection short pass $510 \mathrm{~nm}$, barrier filter bandwidth $525 / 520 \mathrm{~nm}$ ). TRITC fluorescence was visualized using a Leitz (Leica, Wetzlar, Germany) " $\mathrm{N}_{2}$ " filter cube (exciting filter bandpass $530-560 \mathrm{~nm}$, dichroic mirror reflection short pass $580 \mathrm{~nm}$, edge wavelength $580 \mathrm{~nm}$ ). There was no crossdetection between the FITC $\left(\mathrm{L}_{2}\right)$ - and TRITC $\left(\mathrm{N}_{2}\right)$-selective dichroic mirror-filter cubes.

\section{RESULTS}

\section{Desensitization of 5-HT receptors blocks the peristaltic reflex}

An in vitro preparation of the distal region of the guinea pig large intestine was used to analyze the role of 5-HT and the 5-HT transporter in the peristaltic reflex. The reflex was initiated by inserting an artificial fecal pellet into the lumen (oral end); the
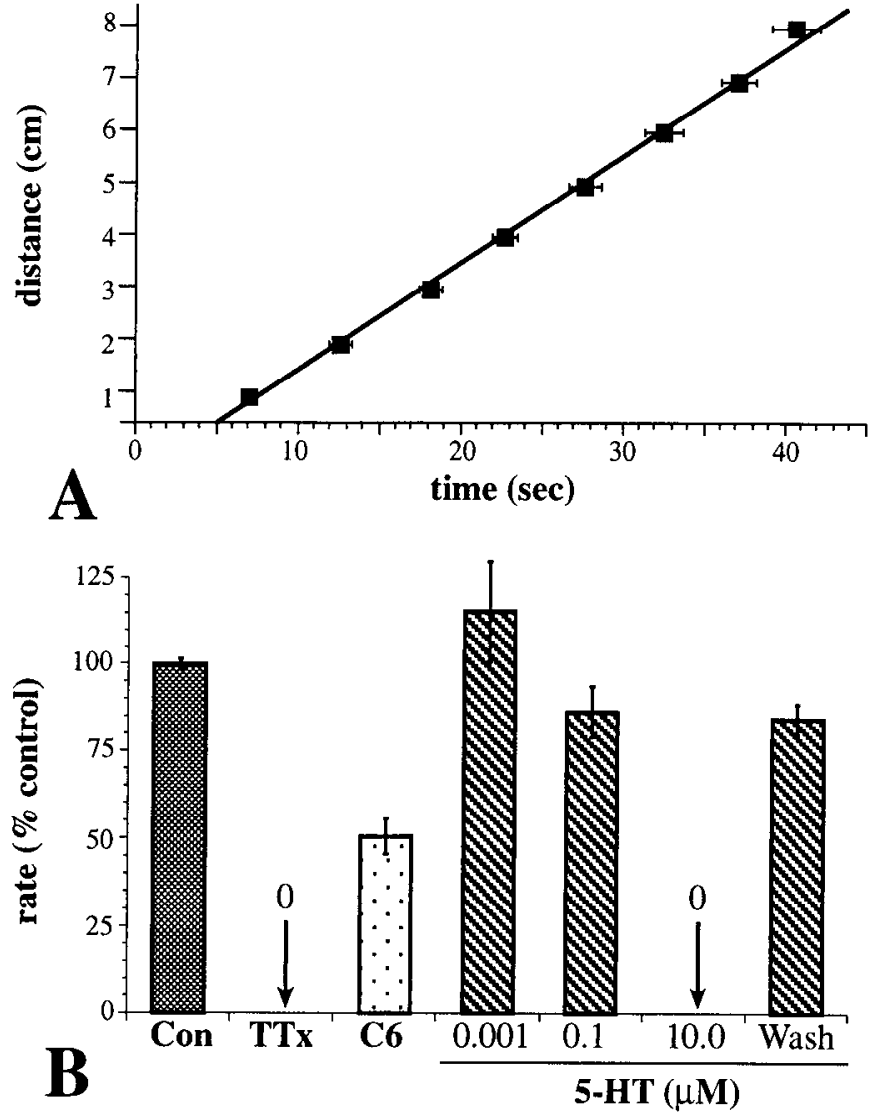

Figure 2. The reflex-initiated rate of propulsion of an artificial fecal pellet in vitro is reproducible, neurally mediated, and inhibited by desensitization of 5-HT receptors. $A$, The distance $(\mathrm{cm})$ traversed by an artificial fecal pellet is plotted as a function of time. I'ime 0 represents the moment the pellet is inserted. The points represent the means of 10 trials, repeated at intervals of $5 \mathrm{~min}$, in three separate segments of gut from one guinea pig. The horizontal bars indicate the SEM. Note that after an initial delay, during which the reflex is evoked, the pellet travels at a linear rate and this rate remains virtually constant. $B$, The peristaltic reflex is abolished by tetrodotoxin (TTx; $0.1 \mu \mathrm{M} ; n=3$ preparations) and inhibited by hexamethonium (C6;10.0 $\mu \mathrm{M} ; n=3$ preparations). Desensitization of 5-HT receptors, by exposure to high concentrations of $5-\mathrm{HT}$, reversibly abolishes the peristaltic reflex (multiple preparations from 7 animals).

rate at which the pellet was transported proximodistally by the bowel was then monitored. This rate proved to be remarkably constant through multiple trials extending over long periods of time (Fig. $2 A$ ). The reflex-driven propulsion of the artificial fecal pellet was blocked by tetrodotoxin $(0.1 \mu \mathrm{M})$ (Fig. $2 B)$, indicating that it is nerve-dependent. The reflex was also inhibited, but not abolished, by hexamethonium $(10 \mu \mathrm{M}$ ) (Fig. $2 B$ ), suggesting that a nicotinic synapse is present in the reflex pathway, although parallel non-nicotinic pathways may also exist. Finally, the reflexdriven propulsion of the fecal pellets was blocked by a sustained application of a high concentration of 5-HT to desensitize 5-HT receptors (Fig. $2 B$ ). This desensitizing effect of 5-HT was concentration-dependent and reversible. The observation that 5-HT desensitization abolishes reflex-driven propulsion suggests that 5-HT-mediated transmission plays a critical role in the peristaltic reflex pathway in the guinea pig distal colon. We therefore determined the effect on the reflex of subtype-selective 5-HT antagonists.

The selective 5-HT $1 \mathrm{P}$ antagonist 5-HTP-DP inhibited the rate of propulsion of the artificial pellets in the distal colon (Fig. $3 A$ ). 

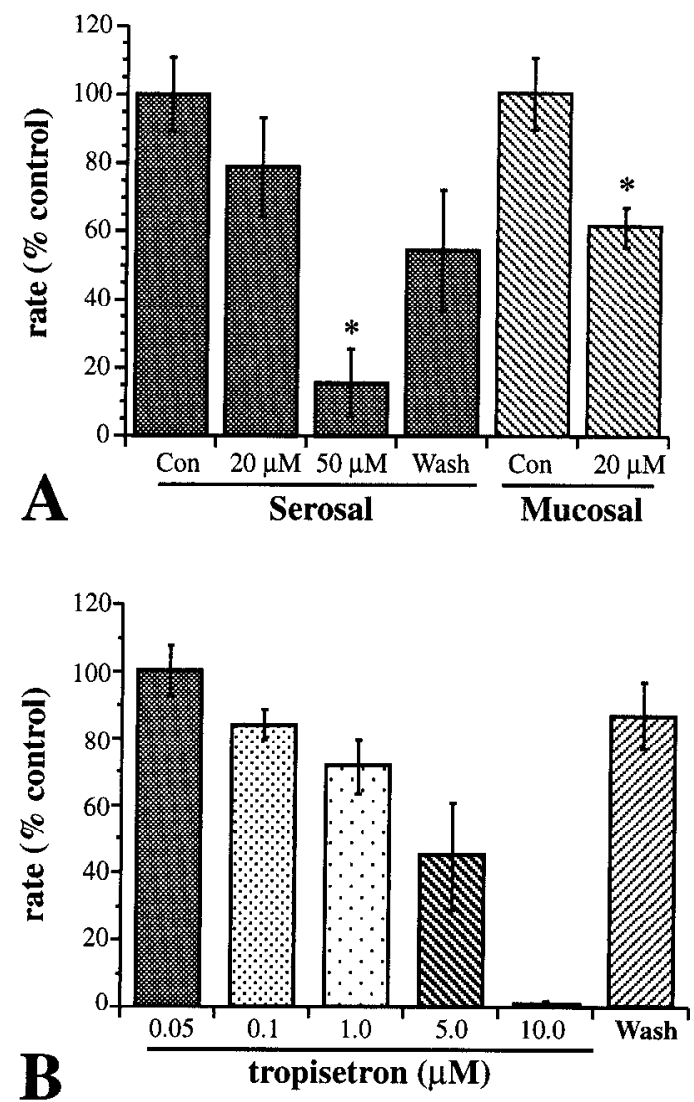

Figure 3. The reflex-initiated rate of propulsion of an artificial fecal pellet in vitro is blocked by a $5-\mathrm{HT}_{1 \mathrm{P}}$ and a $5-\mathrm{HT}_{3 / 4}$ antagonist. $A$, lihe peristaltic reflex is reversibly inhibited by the selective $5-\mathrm{HT}_{1 \mathrm{P}}$ antagonist 5-HTP-DP. A lower concentration of 5-HTP-DP is required to inhibit reflex-activated propulsion when the compound is applied to the mucosal rather than to the serosal surface of the bowel. $\left({ }^{*} p<0.003\right.$ vs control; multiple trials in preparations from 2 animals). $B$, The peristaltic reflex is reversibly inhibited by tropisetron, which is a selective $5-\mathrm{HT}_{3}$ antagonist at concentrations $<1.0 \mu \mathrm{M}$, but also antagonizes $5-\mathrm{HT}_{4}$ receptors at higher concentrations (multiple preparations from 7 animals).

5-HTP-DP was effective in this regard, hoth when it was added to the solution in the organ bath and when it was added as a bolus to the solution in the lumen of the gut (Fig. 3A); however, 5-HTP-DP seemed to be a more effective inhibitor of the reflex when it was applied intraluminally. For example, intraluminal application of $20 \mu \mathrm{M} 5$-HTP-DP decreased propulsion significantly $(p<0.003)$; however, the same concentration of 5-HT was ineffective when added to the bath (serosal). A 5-HTP-DP concentration of $50 \mu \mathrm{M}$ was needed to inhibit propulsion significantly ( $p<0.001$ ) when the compound was added to the bathing solution. These observations are consistent with the idea that 5-HTP-DP gains access to the site in the wall of the colon at which it acts more effectively from the mucosal than from the serosal surface of the bowel. A second subtype-selective 5-HT antagonist that inhibited the propulsion of artificial pellets was tropisetron, which at concentrations below $1 \mu \mathrm{M}$ antagonizes only $5-\mathrm{HT}_{3}$ receptors but at higher concentrations blocks both $5-\mathrm{HT}_{3}$ and $5-\mathrm{HT}_{4}$ sites. Tropisetron had no effect on the reflex at low, $5-\mathrm{HT}_{3}$-selective concentrations (Fig. $3 B$ ). This finding is consistent with the report that $5-\mathrm{HT}_{3}$-selective antagonists fail to influence the peristaltic reflex in the guinea pig distal colon (Kadowaki et al., 1993). Tropisetron was found to inhibit reflex-driven propulsion at $5.0 \mu \mathrm{m}$ and abolished it at $10.0 \mu \mathrm{M}$. These data suggest
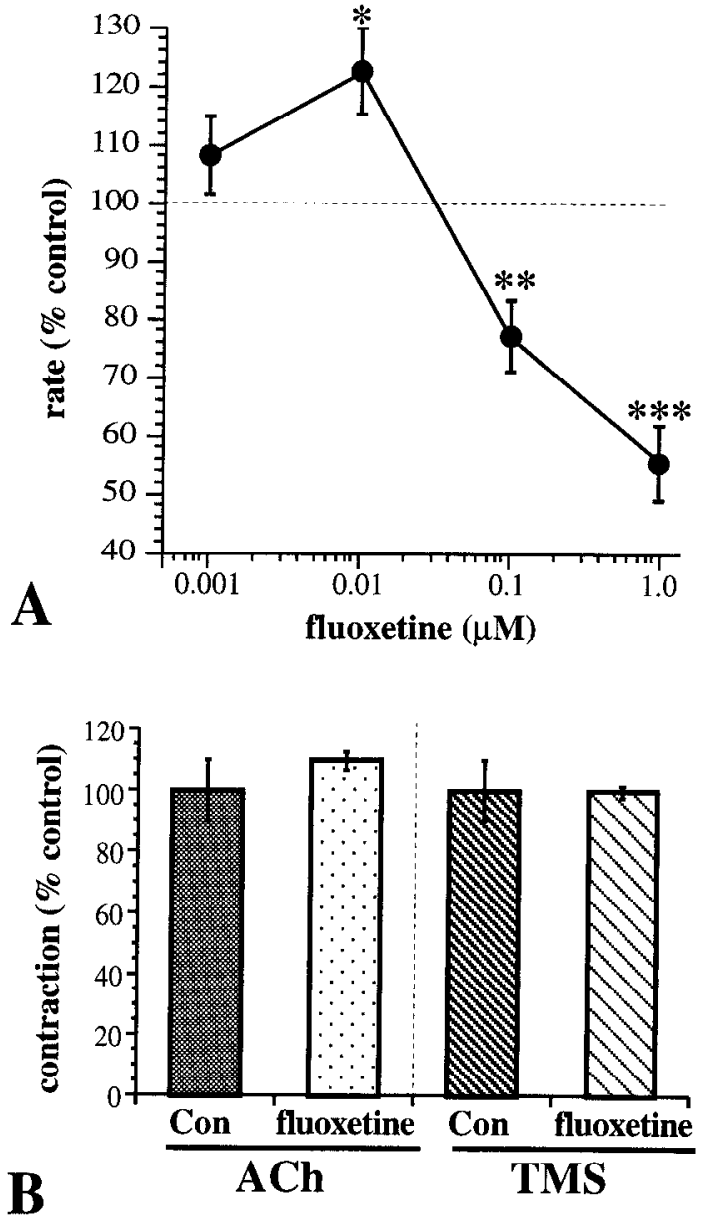

Figure 4. The reflex-initiated rate of propulsion of an artificial fecal pellet in vitro is potentiated by a low concentration but inhibited by higher concentrations of fluoxetine. $A$, The rate of propulsion is plottcd as a function of the concentration of fluoxetine. The increase in the rate at 0.01 $\mu \mathrm{M}$ is significant ( ${ }^{*} p<0.05 \mathrm{vs}$ control). The decreases observed at $0.1 \mu \mathrm{M}$ and $1.0 \mu \mathrm{M}$ are also significant $\left({ }^{* *} p<0.01\right.$ vs control; ***p $p<0.001$ vs control; multiple preparations from 6 animals). $B$, Fluoxetine $(1.0 \mu \mathrm{M})$ does not nonspecifically affect either the amplitude of the contractile response evoked by $\mathrm{ACh}$ or that evoked by transmural electrical stimulation (TMS) (preparations from 4 animals). Con, Control.

that antagonism of $5-\mathrm{HT}_{4}$ receptors is necessary for tropisetron to inhibit the propulsion of pellets in the guinea pig colon. 5- $\mathrm{HT}_{4}$ selective antagonists, however, have been reported not to inhibit the peristaltic reflex in the guinea pig distal colon (Kadowaki ct al., 1993). Both 5-HT 3 and 5-HT 4 receptors thus may have to be blocked simultaneously before antagonism of these receptors interferes with the reflex. These observations are consistent with the idea that endogenous 5-HT plays a role in the mediation of the peristaltic reflex and that this function of 5-HT involves more than a single subtype of 5-HT receptor.

The 5-HT-selective uptake inhibitor fluoxetine was found to exert a concentration-dependent effect on the peristaltic reflex. A low concentration of fluoxetine $(0.01 \mu \mathrm{M})$ significantly increased the rate of propulsion of the artificial fecal pellets (Fig. $4 A)$. In contrast, higher concentrations of fluoxetine $(\geq 0.1 \mu \mathrm{M})$ decreased the rate of propulsion below that seen in control preparations. The degree of inhibition of pellet movement became more intense as a function of the fluoxetine concentration. Once fluoxetine inhibited propulsion, the effects were 

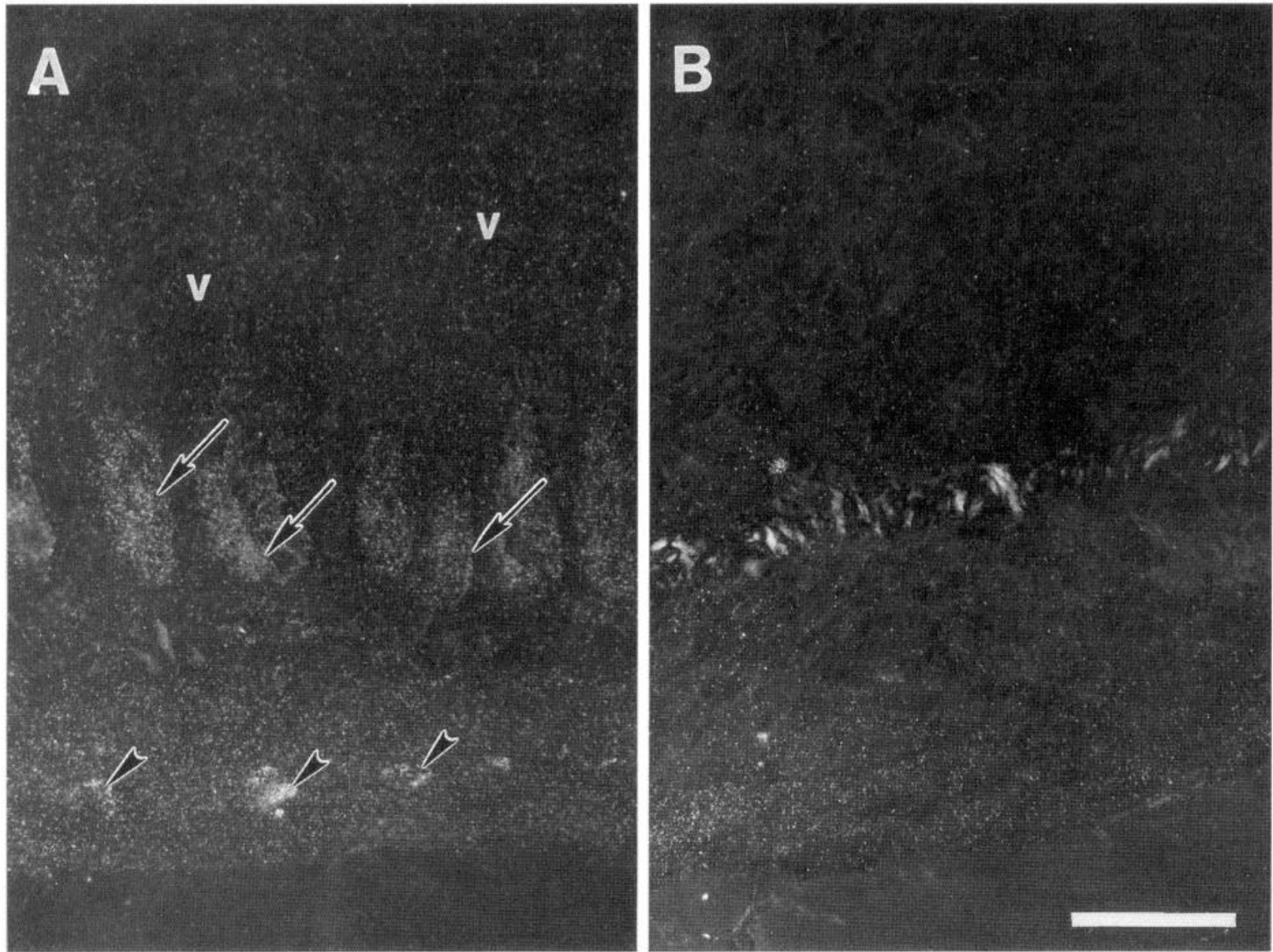

Figure 5. Crypt epithelial cells and enteric neurons specifically take up ${ }^{3} \mathrm{H}-5-\mathrm{HT}$. Cells that took up ${ }^{3} \mathrm{H}-5$-HT were located in the rat intestine by radioautography. $A$, The arrows indicate foci of intense labeling over the epithelium of the basolateral regions of intestinal crypts of Lieberkühn and over ganglia of the myenteric plexus (arrowheads). Labeling is absent from the epithelium lining the wall of villi $(v)$. $B$, Fluoxetine (1.0 $\mu \mathrm{M})$ abolishes ${ }^{3} \mathrm{H}-5$ - $\mathrm{HT}$ uptake. Birefringent collagen fibers are visible in the submucosa; these are brighter in $B$ than in $A$. Scale bar, $100 \mu \mathrm{m}$.

either irreversible during the time frame of the experiments, or they reversed very slowly (after about $1 \mathrm{hr}$ ). Smooth-muscle contractions, however, could still be elicited by mechanical stimulation of the serosal surface (not illustrated). A concentration of fluoxetine $(1.0 \mu \mathrm{M})$ that reduced the peristaltic reflex to about half that of control had no effect on the responses of the preparations to $\mathrm{ACh}(0.12 \mu \mathrm{M})$ or transmural electrical stimulation (TMS) (Fig. 4B). These observations suggest that inhibition of the peristaltic reflex by fluoxetine is not attributable to inhibition of $\mathrm{ACh}$ receptors, nor is it attributable to interference with nerve conduction or with the release of $\mathrm{ACh}$. To confirm that fluoxetine does not interfere nonspecifically with neural mechanisms or responsivity to $\mathrm{ACh}$, advantage was taken of the long-lasting inhibition of pellet motility by fluoxetine. Preparations were exposed to a high concentration of fluoxetine $(10 \mu \mathrm{M})$, which was then washed out; responses to ACh $(0.12 \mu \mathrm{M})$ and TMS were determined 15 min after washout, during the period when pellet motility was still blocked by fluoxetine. Responses to $\mathrm{ACh}$ (rate $=100 \pm 10 \%$ of control) and TMS (90 $\pm 2.3 \%$ of control) were not inhibited significantly. A second 5-HT-selective uptake inhibitor, zimelidine (Takaki et al., 1985), was assessed to evaluate further the specificity of the action of fluoxetine. Like fluoxetine, zimelidine $(5.0 \mu \mathrm{M})$ abolished reflex-activated propulsion of artificial fecal pellets, but the action of zimelidine was more rapidly reversible. The data are thus consistent with the idea that fluoxetine interferes with the peristaltic reflex by causing the desensitization of 5-HT receptors.

\section{5-HT is taken up by crypt epithelial cells as well as by serotonergic neurons in the gut}

Radioautography of tissues incubated with ${ }^{3} \mathrm{H}-5-\mathrm{HT}$ was used to determine whether a mucosal component takes up ${ }^{3} \mathrm{H}-5-\mathrm{HT}$. Because serotonergic elements of the ENS are known to take up ${ }^{3}$ H-5-HT selectively (Gershon et al., 1976; Erde et al., 1985), its uptake by the neuronal structures served as an internal positive control. Initial studies were carried out on segments of guinea pig and rat duodenum. This area of the small intestine was selected because it is the region of the gastrointestinal tract with the highest concentration of EC cells (Penttilä, 1967; Thompson and Campbell, 1967). ${ }^{3} \mathrm{H}-5-\mathrm{HT}$ was taken up by epithelial cells of intestinal crypts, by processes in the neuropil of submucosal and myenteric ganglia, and by nerve cell bodies in myenteric ganglia (Fig. 5A). Additional experiments were carried out with preparations incubated with ${ }^{3} \mathrm{H}-5-\mathrm{HT}$ in the presence of fluoxetine or in $\mathrm{Na}^{+}$-free media to determine whether the pharmacological properties and ionic requirements of the crypt epithelial uptake of ${ }^{3} \mathrm{H}-5-\mathrm{HT}$ are similar to those of serotonergic neurons. The uptake of ${ }^{3} \mathrm{H}-5-\mathrm{HT}$ by enteric (Gershon et al., 1976; Gershon and Jonakait, 1979) and central (Blakely et al., 1991; Hoffman et al., 1991) serotonergic neurons, as well as by non-neuronal cells such as platelets (Rudnick, 1977; Williams and Phillips, 1991) and mast 


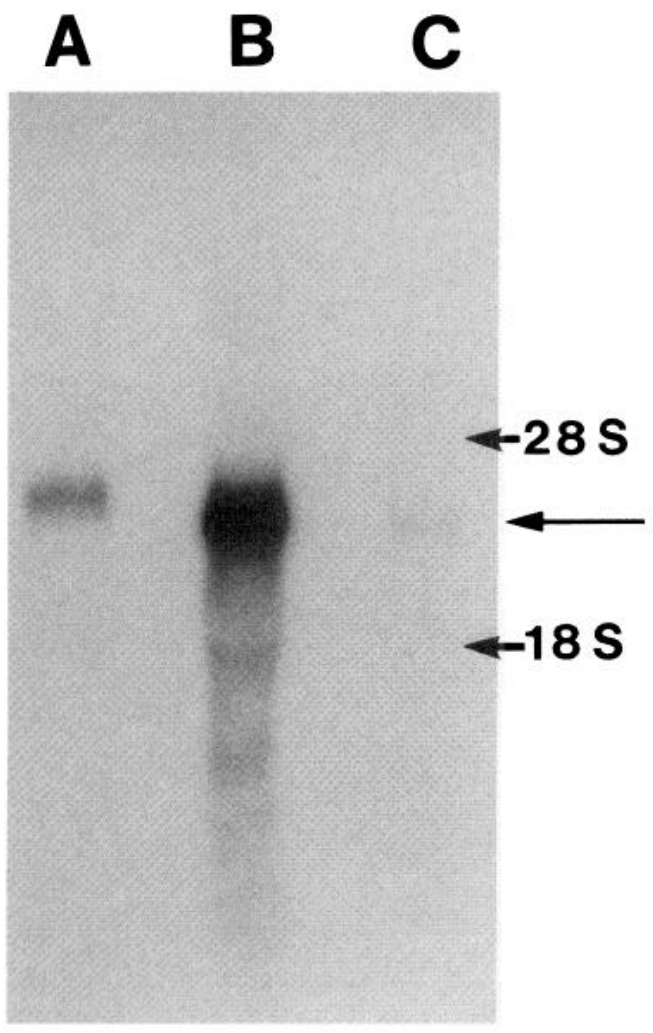

Figure 6. The mucosae of the rat and guinea pig small intestine contain mRNA that hybridizes in Northern blots with a cDNA probe encoding the rat brain 5 -HT transporter. $A$, Total RNA extracted from the rat brain. $B$, Total RNA extracted from the mucosa of the rat small intestine. $C$, Total RNA extracted from the mucosa of the guinea pig small intestine. Positions of $18 S(1950 \mathrm{bp})$ and $28 S(4700 \mathrm{bp})$ ribosomal RNA are indicated.

cells (Hoffman et al., 1991), is $\mathrm{Na}^{+}$-dependent and blocked by fluoxetine. The uptake of ${ }^{3} \mathrm{H}-5-\mathrm{HT}$ by both crypt epithelial cells and neural elements was prevented completely when the tissues were incubated in the presence of fluoxetine (Fig. $5 B$ ) or in the absence of extracellular $\mathrm{Na}^{+}$(not illustrated). These data suggest that the crypt epithelial cells express a 5-HT transporter with properties similar to those found in serotonergic neurons.

\section{mRNA encoding the 5-HT transporter is present in crypt epithelial cells as well as in myenteric neurons}

Northern analysis was used to determine whether mRNA encoding the 5-HT transporter found in rat brain is also expressed in the rat intestinal mucosa. Total RNA was extracted from samples of mucosa scraped from the rat and guinea pig small intestines, with care taken not to remove deeper elements of the wall of the bowel. The blots were probed with a ${ }^{32} \mathrm{P}$-labeled full-length $(2415 \mathrm{bp})$ cDNA probe encoding the rat brain 5-HT transporter. Single hybridizing mRNA species $(\sim 3.7 \mathrm{~kb})$ were found in the rat brainstem (investigated as a positive control) and the rat and guinea pig intestinal mucosa (Fig. 6). The abundance of this message was higher in the rat intestinal mucosa than in the brainstem. The intensity of the hybridizing signal from the guinea pig mucosa, although present, was much less than that from the rat. These blots suggest that mRNA is present in the intestinal mucosa encoding a 5-HT transporter that is similar or identical to that of the brain.

Reverse transcription-PCR was used to assess the degree of identity between the rat intestinal mucosal and brain 5-HT transporters. Both nucleotide and predicted amino acid sequences of the rat mucosal 5-HT transporter were found to be almost iden- tical $(99.8 \%)$ to those reported for the 5-HT transporter cloned from rat brain (Blakely et al., 1991) and the 5-HT transporter cloned from rat basophilic leukemia cells (Hoffman et al., 1991). Only three differences between the mucosal and rat brain 5-HT transporters were found at the nucleotide level, and only two of these would affect the predicted amino acid sequence. These were a change of $A_{59}$ to $G$ and $R_{626}$ to $S$. These small differences could be attributed to PCR, or they may reflect slight strain variations. The observations indicate that the rat mucosa contains mRNA encoding the same 5-HT transporter that is present in serotonergic neurons.

Cells containing mRNA encoding the 5-HT transporter were located in cross-sections of rat intestine by in situ hybridization using a ${ }^{35}$ S-labeled cRNA. Similarly treated serial sections, exposed to a ${ }^{35} \mathrm{~S}$-labeled sense riboprobe, served as controls. Sections of rat brainstem, cut through raphe nuclei, were examined simultaneously with the same reagents as a positive control. Specific labeling was considered to be that seen in sections incubated with the antisense, but not the sense riboprobe. Intense labeling of crypt epithelial cells was observed in sections hybridized with the ${ }^{35}$ S-labeled cRNA (Fig. 7A). These cells were not labeled by the ${ }^{35}$ S-labeled sense riboprobe (Fig. $7 B$ ). The intensity of labeling of epithelial cells was greatest near the base of crypts and declined near the crypt-villus junction. The mature enterocytes lining the walls of villi were not labeled. In addition to the specific labeling of crypt epithelial cells, nonspecific binding of both sense and antisense probes to scattered small cells in the lamina propria also occurred (Figs. $7 A, B$ ). The same probe that was used to detect mRNA encoding the 5-HT transporter in the bowel labeled the cell bodies of serotonergic neurons in the dorsal nucleus of the median raphe (Fig. $7 C$ ). No dorsal raphe neurons were labeled by the ${ }^{35}$ S-labeled sense riboprobe (Fig. $7 D$ ).

In contrast to sections through the median raphe, almost no neurons in either the submucosal or myenteric plexuses were found to be labeled by the ${ }^{35} \mathrm{~S}$-cRNA probe in sections of the rat duodenum. We thought that this seemingly paradoxical result might be attributable to the relative paucity of enteric serotonergic nerve cell bodies and their scattered distribution. In contrast to the transporter itself, which mediates the uptake of 5 -HT by axons, mRNA is essentially confined to the cell bodies and dendrites of neurons. Enteric serotonergic neurons in rodents have been demonstrated to be limited to the myenteric plexuses, where they comprise about $3 \%$ of the total number of neurons (Costa et al., 1982; Furness and Costa, 1982; Gershon and Sherman, 1987). Cross-sections of duodenum, therefore, would rarely pass through the cell body of a serotonergic neuron. To determine whether enteric serotonergic neurons actually do express mRNA encoding the same 5-HT transporter as their central counterparts, digoxigeninlabeled riboprobes were used to locate mRNA encoding the 5-HT transporter by in situ hybridization in whole mounts of LMMP. Bound probes were detected by immunocytochemistry. Sections of brainstem were examined again with the same digoxigenin-labeled riboprobes as a positive control, and sense probes were used to evaluate the specificity of labeling. Myenteric neurons in the whole-mount LMMP preparations were found to be labeled by the antisense but not the sense riboprobe (Fig. $8 A-C$ ). When preparations were exposed to the sense riboprobe, the entire myenteric plexus was devoid of labeling. Labeling by the antisense riboprobe was confined to the cell bodies of these neurons and to the most proximal regions of processes, which were interpreted as dendrites. The 

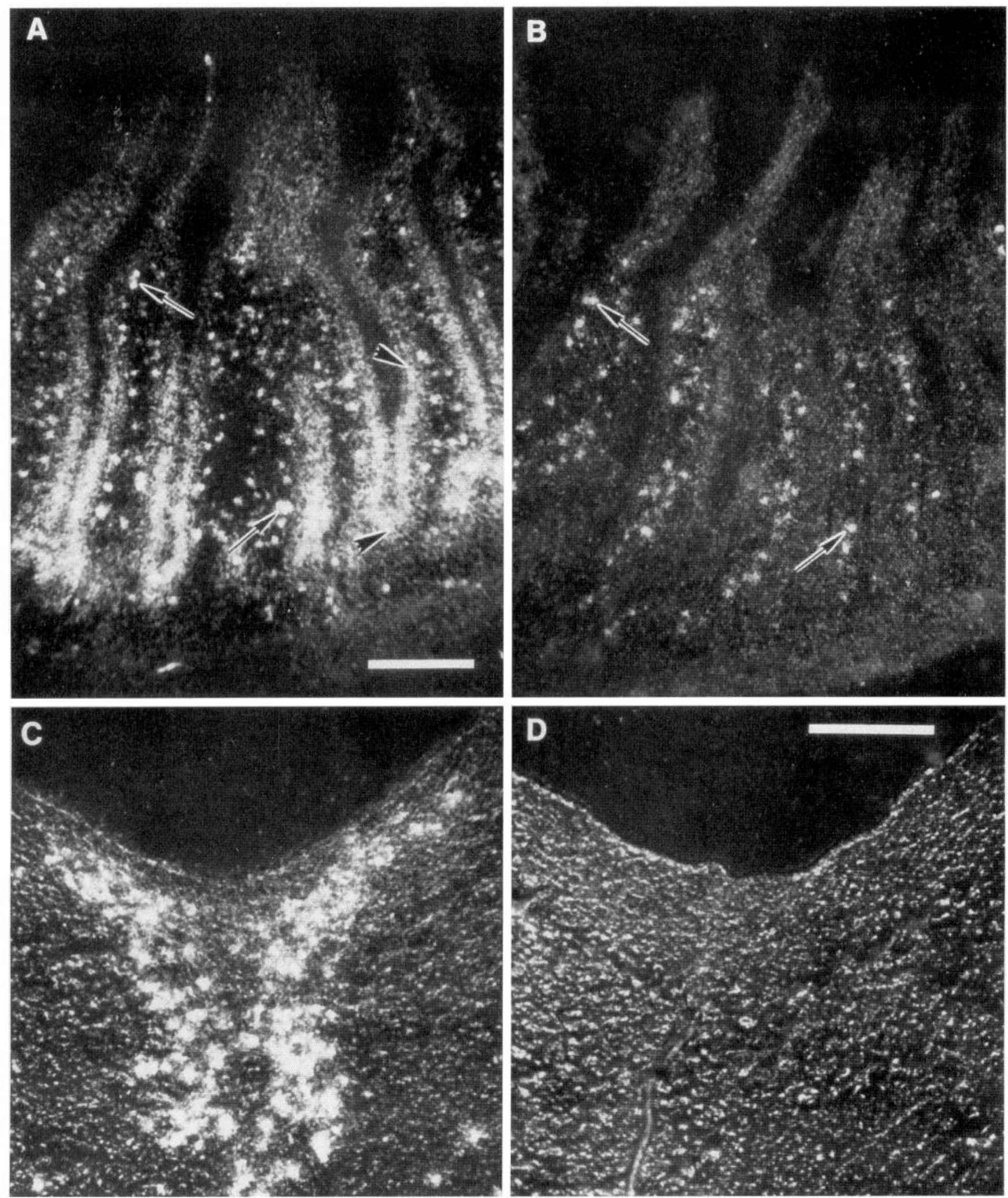

Figure 7. Crypt epithelial cells of the rat small-intestine mucosa contain mRNA encoding the 5-HT transporter. In situ hybridization with a ${ }^{35}$ S-labeled antisense riboprobe was used to locate mRNA encoding the 5-HT transporter in the rat small intestine. The dorsal nucleus of the median raphe was also investigated as a positive control. Alternate sections incubated with a sense probe were used as negative controls. Specific labeling was considered to be that visualized with the antisense but not the sense probe. $A$, Rat small intestine incubated with the antisense riboprobe. The crypt epithelium (arrowheads) is intensely labeled. Note that the location of the hybridizing cells corresponds to that of cells found by radioautography to specifically take up ${ }^{3} \mathrm{H}-5$-HT (compare with Fig. 5). No labeling is seen in myenteric ganglia in the intestinal wall. Structures indicated by the arrows are labeled nonspecifically because they also bind the sense riboprobe. $B$, Control rat small intestine incubated with the sense riboprobe. The crypt epithelium is not labeled. Some cells are labeled nonspecifically (arrows). $C$, Rat brainstem hybridized with the antisense probe. Neurons are labeled in the dorsal raphe nucleus. $D$, Rat brainstem hybridized with the sense probe. No cells are labeled. Scale bars, $100 \mu \mathrm{m}$. 

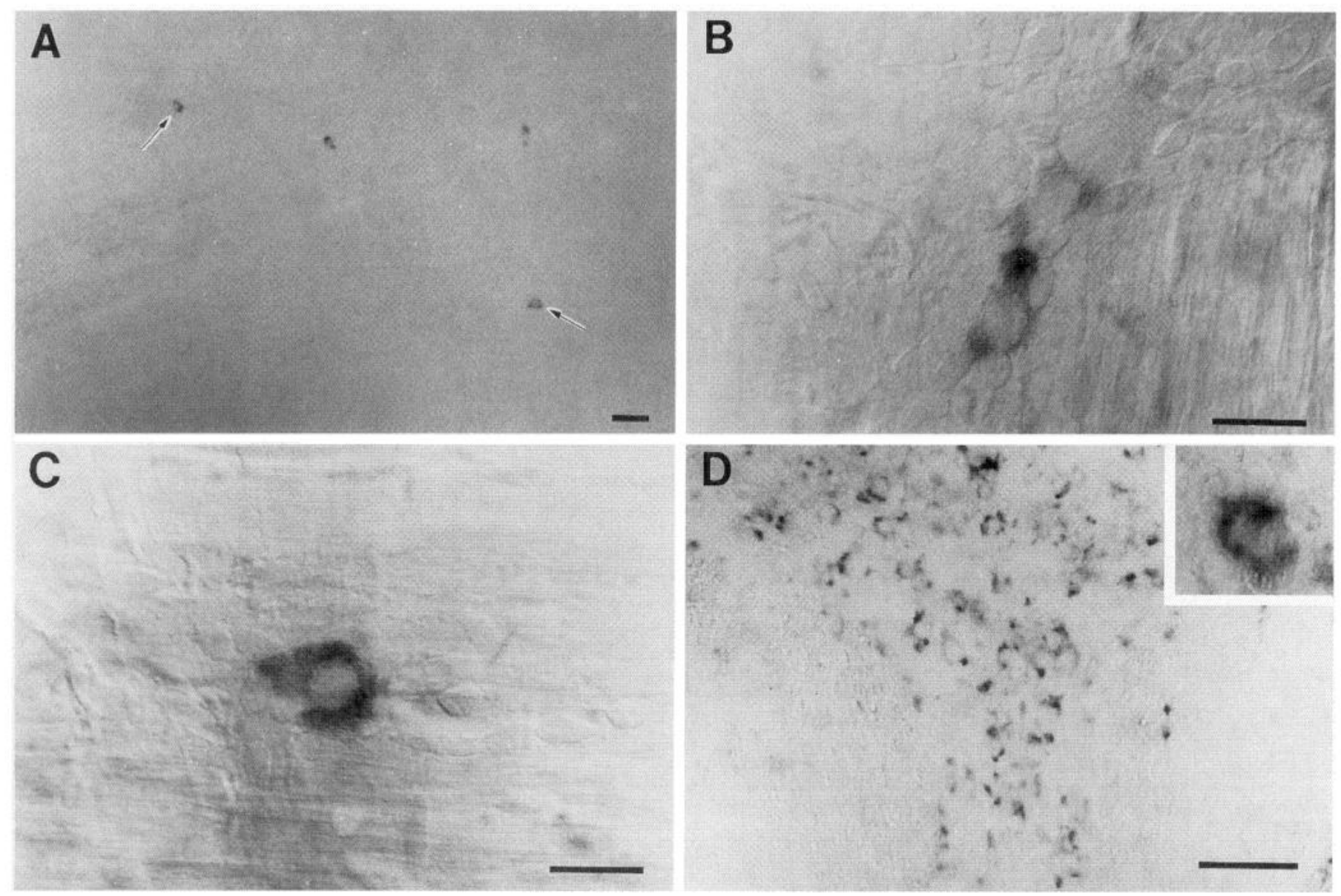

Figure 8. Neurons of the rat small intestine myenteric plexus contain mRNA encoding the 5-HT transporter. In situ hybridization with a digoxigeninlabeled antisense riboprobe was used to locate mRNA encoding the 5-HT transporter in strips of longitudinal muscle with attached myenteric plexus dissected from the rat small intestine. Preparations were examined as whole mounts; bound probe was visualized immunocytochemically with monoclonal antibodies to digoxigenin. The dorsal nucleus of the median raphe was also investigated as a positive control. A, Scattered cells (arrows) hybridize with the antisense probe. $B$ and $C$, At higher magnification, the cells that contain mRNA encoding the 5-HT transporter can be identified as myenteric neurons. Differential interference contrast optics were used to visualize the outlines of nonlabeled cells. $D$ and insert, Rat brainstem hybridized with the antisense probe. Neurons are labeled in the dorsal raphe nucleus. Scale bars: $A, 100 \mu \mathrm{M} ; B$ and $C, 50 \mu \mathrm{m} ; D, 100 \mu \mathrm{m} ;$ insert, $50 \mu \mathrm{m}$.

packing density of these neurons was relatively low, about the same as that reported for serotonergic neurons revealed by immunocytochemistry with antibodies to 5-HT (Costa et al., 1982; Furness and Costa, 1982) or radioautography of tissue incubated with ${ }^{3}$ H-5-HT (Gershon and Sherman, 1987; Gershon et al., 1990). The same digoxigenin-labeled antisense (but not the sense) riboprobe used to detect mRNA encoding the 5-HT transporter in LMMP preparations labeled the cell bodies of serotonergic neurons in the dorsal nucleus of the median raphe (Fig. $8 D$ ). These observations suggest that mRNA encoding the same 5-HT transporter that is expressed by neurons of the median raphe is also expressed by enteric neurons and crypt epithelial cells in the bowel.

\section{5-HT transporter immunoreactivity is present in crypt epithelial cells and enteric serotonergic neurons}

Immunocytochemical studies were carried out with antibodies to the rat brain $5-\mathrm{HT}$ transporter to determine whether the protein itself is expressed by crypt epithelial cells and enteric neurons. The antibodies that were used were raised in rabbits against a glutathione- $S$-transferase fusion protein that encompassed the final 34 amino acids (597-630) of the rat brain 5-HT transporter (Qian et al., 1995). The antibodies selectively rec- ognize both brain and platelet isoforms of the 5-HT transporter expressed in heterologous cell systems and native tissues. Furthermore, the immunocytochemical distribution of sites in the rat brain labeled by the affinity-purified antibodies to the 5-HT transporter has been shown to overlap with sites labeled by antibodies to 5-HT. A subset of crypt epithelial cells was found to be immunocytochemically labeled by antibodies to the 5 -HT transporter in sections of rat and guinea pig small intestine (Fig. $9 A$ ). Crypt epithelial cells were also labeled by these antibodies in the colon (not illustrated) of the rat and guinea pig. No labeling was seen when the primary antibodies were omitted (Fig. 9B). The cells that were labeled by the antibodies to the 5 -HT transporter were not themselves 5-HT-immunoreactive when double-label immunocytochemistry was carried out (Fig. 9C,D). The antibodies to the 5-HT transporter immunostained both varicose axons and nerve cell bodies in whole mounts of rat LMMP preparations (Fig. 10A-D). The number of 5-HT transporterimmunoreactive nerve cell bodies was comparable to that of neuronal perikarya expressing mRNA encoding the 5-HT transporter (Fig. $8 \mathrm{~A}$ ); however, the antibody demonstrated the axons of labeled cells that were not visualized by in situ hybridization. The pattern of fibers and the distribution of nerve cell 

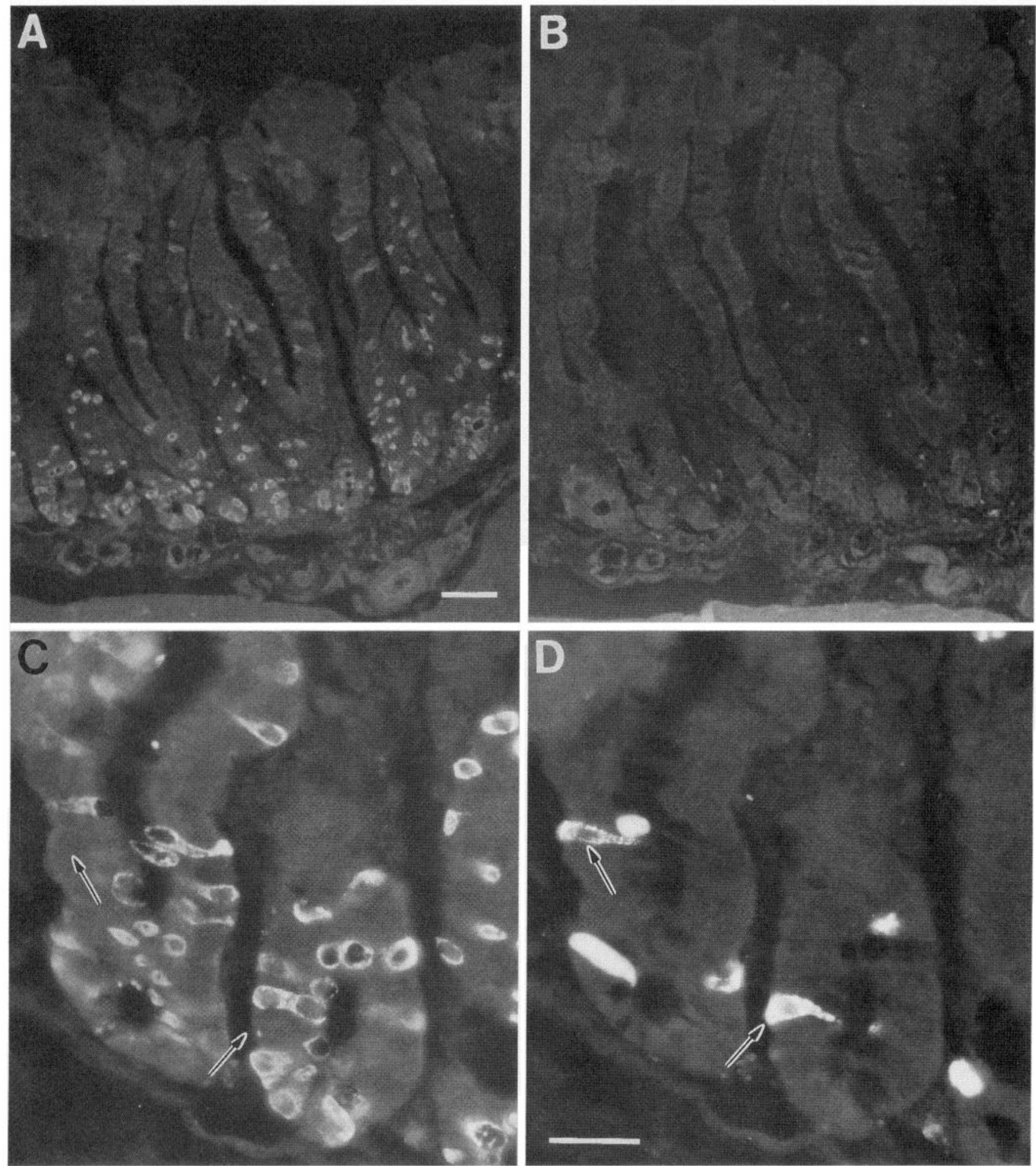

Figure 9. The immunoreactivity of the 5-HT transporter protein is present in crypt epithelial cells of the rat small intestine. The immunoreactivities of the 5-HT transporter (TRITC) and 5-HT (FITC) were located by double-label immunocytochemistry in frozen sections of rat small intestine. $A$, TRITC 5-HT transporter-immunoreactive cells are most numerous in the epithelium of the basolateral regions of crypts. This location corresponds to that of cells found radioautographically to take up ${ }^{3} \mathrm{H}-5-\mathrm{HT}$ and to contain mRNA encoding the 5-HT transporter. $B$, TRITC (control). There is no labeling of cells when the primary antibody is omitted. $C$, TRITC. At higher magnification the 5-HT transporter immunoreactivity can be seen to be concentrated in the peripheral cytoplasm and plasma membrane. Nuclei are not labeled. $D$, FITC 5-HT immunoreactivity is demonstrated in the same section $(C)$ used to visualize the immunoreactivity of the 5-HT transporter. Most of the EC cells, identified by their content of 5-HT immunoreactivity, do not coincidentally express the 5-HT transporter. Arrows show the location of the EC cells, which are fluorescent in $D$ but not in $C$. Scale bars, $50 \mu \mathrm{m}$. 

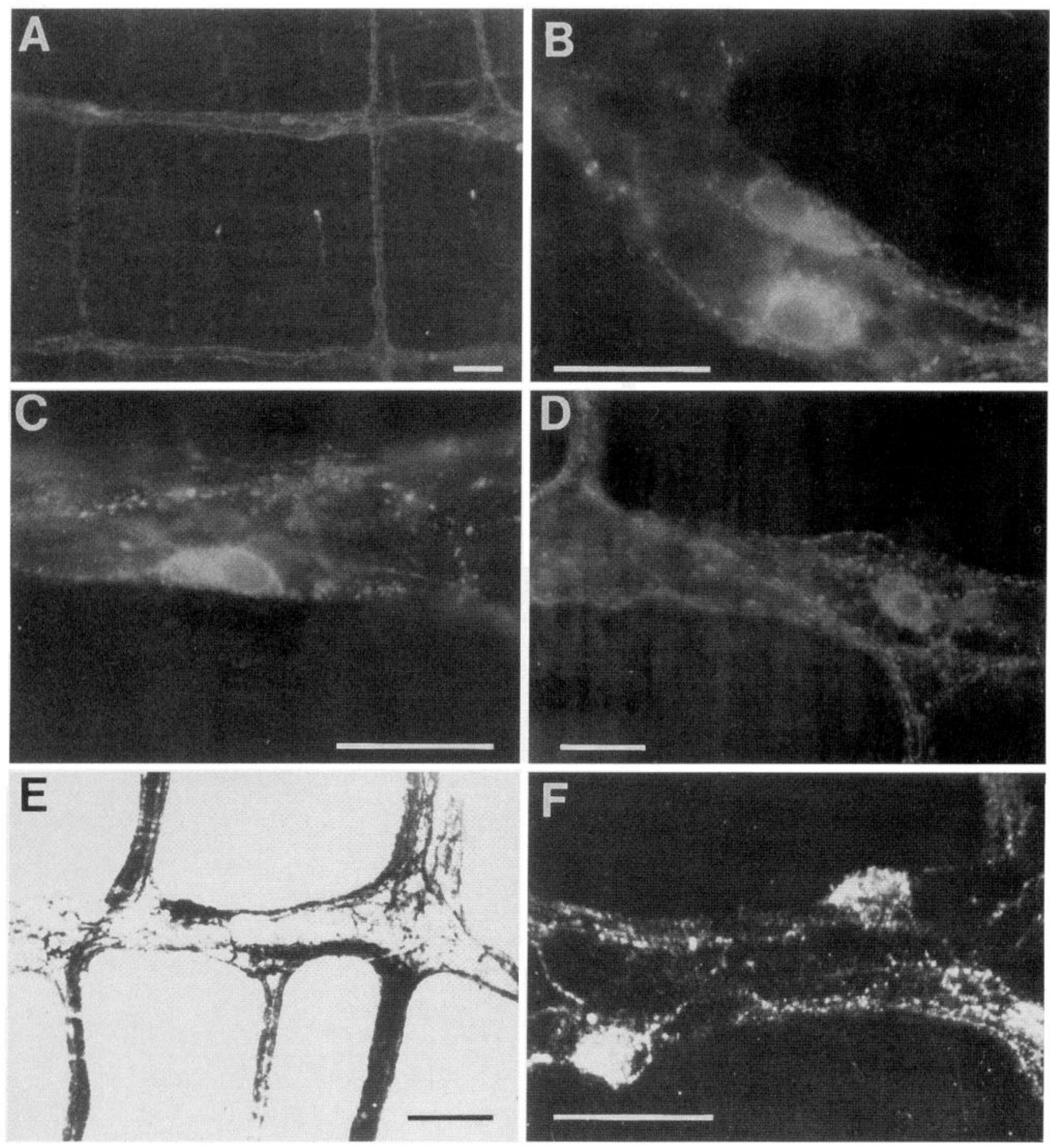

Figure 10. The immunoreactivity of the 5-HT transporter protein is present in myenteric neurons of the rat small intestine. 5-HT transporter immunoreactivity was demonstrated in whole mounts prepared from the rat small intestinal LMMP. $A$, Scattered neuronal perikaya are 5-HT transporter-immunoreactive. The numbers of such cells are similar to those found by in situ hybridization to contain mRNA encoding the 5-HT transporter (compare with Fig. 8A). In contrast to the mRNA, however, 5-HT transporter immunoreactivity is present in axons as well as in the nerve cell bodies. $B-D$, At higher magnification, the varicose nature of 5-HT transporter-immunoreactive axons can be seen. The occurrence of two or more 5-HT-immunoreactive neurons in a single ganglion $(B)$ is uncommon; more frequently, ganglia contain only one $(C, D)$. The location of the neurons is often at the ganglionic surface $(B, C)$. $E$ and $F$, Whole-mount radioautographs showing the location of elements in the guinea pig myenteric plexus that take up ${ }^{3} \mathrm{H}-5-\mathrm{HT}$. Note that the pattern is similar to that of 5 -HT transporter-immunoreactive elements of the myenteric plexus. Scale bars: $A, 100 \mu \mathrm{m} ; B-F, 50 \mu \mathrm{m}$.

bodies labeled by the antibodies to the 5 -HT transporter in the whole mounts was comparable, in similar preparations, to those of fibers and perikarya that take up radioautographically detectable ${ }^{3} \mathrm{H}-5-\mathrm{HT}$ (Fig. 10E,F).

\section{DISCUSSION}

The role played by mucosal secretion of 5-HT in evoking the peristaltic reflex has been a conundrum. This role seems to be critical: EC cells secrete 5-HT in response to pressure or mucosal distension 
(Feldberg and Toh, 1953; Bülbring and Crema, 1959b; Grider et al., 1994; Foxx-Orenstein et al., 1995). This 5-HT stimulates the intrinsic sensory neurons that initiate the peristaltic (Kirchgessner et al., 1992; Grider et al., 1994; Foxx-Orenstein et al., 1995) or secretory reflexes (Cooke and Reddix, 1994). The mechanism of mucosal 5-HT inactivation, however, has not been known. If 5-HT is the transmitter at an EC cell-sensory nerve junction, then mucosal 5 -HT will have to be removed rapidly to terminate responses to it and prevent receptor desensitization. Indeed, an inactivating mechanism is a criterion used in identifying neurotransmitters (Burnstock, 1983). The present investigation was thus carried out to identify the putative mechanism for the inactivation of mucosal 5-HT. We tested the hypothesis that the same plasmalemmal 5-HT transporter that is expressed by serotonergic neurons and accounts for the inactivation of 5-HT at synapses in the nervous system is expressed in the mucosa. Because the mucosa contains no serotonergic nerves (Costa et al., 1982; Furness and Costa, 1982), the cells that express this transporter would have had to be either nonserotonergic neurons or non-neuronal cells. Our data suggest that uptake of 5-HT in the mucosa plays a necessary role in the peristaltic reflex by preventing the desensitization of 5-HT receptors. Mucosal uptake of 5-HT occurs because crypt epithelial cells synthesize and express a functional 5-HT transporter in their plasma membrane.

Evidence that 5-HT inactivation is important in the peristaltic reflex was derived from in vitro studies of the reflex-activated propulsion of artificial fecal pellets in the guinea pig distal colon. The peristaltic reflex was evoked reproducibly in this preparation for long periods of time. Because the in vitro reflex was blocked by tetrodotoxin and inhibited by hexamethonium, it was nervedependent. The reflex was also dependent on intact serotonergic mechanisms, because propulsive activity was abolished by desensitization of 5-HT receptors. The effectiveness of tropisetron, a $5-\mathrm{HT}_{3} / 5-\mathrm{HT}_{4}$ dual antagonist, and 5-HTP-DP, a 5-HT $1 \mathrm{P}$ antagonist, in inhibiting propulsion suggested that both $5-\mathrm{HT}_{3} / 5-\mathrm{HT}_{4}$ (Kadowaki et al., 1993) and $5-\mathrm{HT}_{1 \mathrm{P}}$ receptors participate in the reflex. The observation that 5-HTP-DP was more effective when applied to the mucosal rather than the serosal surface of the colon suggests that 5-HTP-DP acts on the mucosa. 5-HT $1 \mathrm{P}$ receptors have been located in the mucosal nerve plexus that underlies the intestinal epithelium (Wade et al., 1994), and 5-HT $\mathrm{TP}_{\mathrm{P}}$ receptors have been implicated in the activation of the intrinsic sensory neurons in the submucosal plexus that initiate the peristaltic reflex (Kirchgessner et al., 1992; Foxx-Orenstein et al., 1995). A site of action on mucosal sensory nerves thus would account for the observed effectiveness of 5-HTP-DP. These observations supported the use of the guinea pig distal colon to test the prediction that blocking the uptake of 5-HT would interfere with the peri staltic reflex.

The actions of fluoxetine and zimelidine, selective inhibitors of 5-HT uptake, supported the hypothesis that the 5-HT transporter plays a role in the peristaltic reflex. A low concentration of fluoxetine potentiated the propulsion of fecal pellets; nevertheless, propulsion was inhibited by fluoxetine at concentrations above $0.1 \mu \mathrm{m}$. These observations could be explained if a moderate degree of inhibition of 5-HT uptake by fluoxetine enhances the action of endogenous 5-HT to accelerate propulsion but more complete inhibition of uptake causes 5-HT receptors to desensitize, inhibiting the reflex. The similar action of zimelidine supports the idea that 5-HT accumulation accounts for reflex inhibition; however, nonspecific antagonism of a 5-HT receptor subtype by fluoxetine was not excluded rigorously. Fluoxetine did not affect cholinergic transmission or nerve-driven muscle contraction and thus evidently did not interfere nonspecifically with reflexdriven motility. Physiological experiments alone do not identify which of the potential sites of action of 5-HT are affected by drugs. Because 5-HT is a neurotransmitter of myenteric neurons, as well as a product of EC cells, interference with serotonergic transmission could antagonize the peristallic reflex at sites in the mucosa or in the myenteric plexus. Although the peristaltic reflex depends on serotonergic transmission, receptor desensitization, 5-HTP-DP, tropisetron, and fluoxetine/zimelidine could have antagonized the reflex in the guinea pig distal colon by blocking the effect of 5-HT on either mucosal sensory nerves or myenteric neurons.

A functional 5-HT transporter was indeed found to be expressed in the mucosa. This transporter was localized to crypt epithelial cells by radioautography; thus, these cells took up ${ }^{3} \mathrm{H}-5-\mathrm{HT}$ by a $\mathrm{Na}^{+}$-dependent mechanism that was inhibited by fluoxetine. Fluoxetine was shown previously to block mucosal uptake of radiolabeled 5-HT in the rat, although that study assumed that 5-HT was taken up by EC cells (Ternaux et al., 1981). Most of the EC cells, identified immunocytochemically in the current study by their content of endogenous 5-HT, did not become labeled by ${ }^{3} \mathrm{H}-5-\mathrm{HT}$. Conceivably, crypt cells might have been mistaken for EC cells in the previous investigation of the rat mucosa. It seems likely that the uptake of 5-HT by crypt epithelial cells enables the mucosal epithelium to act as a 5-HT sink. The uptake of 5-HT by crypt epithelial cells does not prevent the diffusion of 5-HT secreted by EC cells into the lumen of the bowel (Ahlman et al., 1981a,b) or from absorption into blood vessels (Toh, 1954); nevertheless, the presence of the epithelial sink probably causes the concentration of 5-HT in the lamina propria to fall more rapidly, after its secretion by EC cells, than it would have in the absence of the crypt epithelial 5-HT transporter. An apparent barrier, which impedes the mucosal to serosal passage of ${ }^{3} \mathrm{H}-5-\mathrm{HT}$, has been reported previously (Gershon and Tamir, 1981; Cooke et al., 1983). This barrier could be accounted for by the existence of a mucosal 5-HT sink.

Northern analysis indicated that mRNA hybridizing with a full-length cDNA probe encoding the rat brain 5-HT transporter is present in the intestinal mucosa of both guinea pigs and rats, confirming previous data from rat bowel (Hoffman et al., 1991). This mucosal mRNA was about the same size $(3.7 \mathrm{~kb})$ as hybridizing mRNA extracted from rat brainstem and encoded a molecule that was virtually identical in sequence to the rat brain 5-HT transporter (Blakely et al., 1991). mRNA encoding the 5-HT transporter was also found by Northern analysis to be more abundant in the rat intestinal mucosa than in the rat brainstem. Less hybridizing mRN $\Lambda$ was detected in the guinea pig mucosa, probably because the sequence of the guinea pig 5-HT transporter is not identical to that of the rat. In situ hybridization revealed that cells that contain mRNA encoding the 5-HT transporter were located in exactly the same region of the crypt epithelium as the cells found by radioautography to take up ${ }^{3} \mathrm{H}-5-\mathrm{HT}$. These cells were most abundant in the basolateral region of intestinal crypts and declined in number along the crypt-to-villus axis. This distribution corresponds to the proliferative zone of epithelial precursor cells (Gordon et al., 1992). These crypt epithelial cells are known to be secretory (Welsh et al., 1982), and intestinal $\mathrm{Cl}^{-}$ secretion is stimulated by 5-HT (Cooke and Reddix, 1994). 5-HT also stimulates the proliferation of crypt epithelial cells (Tutton, 1974). The 5-HT transporter thus may play a role in epithelial actions of 5-HT.

5-HT transporter-immunoreactive cells were observed to be 
present in the same regions of the intestinal crypts as the cells that contain mRNA encoding the transporter and take up ${ }^{3} \mathrm{H}-5-\mathrm{HT}$. The transporter protein thus is expressed by crypt epithelial cells and probably accounts for their uptake of ${ }^{3} \mathrm{H}-5-\mathrm{HT}$. The location of 5-HT transporter-immunoreactive cells, however, was not absolutely identical to that of cells revealed by in situ hybridization. Some villus cells contained 5-HT transporter immunoreactivity but not the corresponding mRNA. This difference suggests that the 5-HT transporter continues to be present in a subset of epithelial cells after they ascend beyond the crypt-villus junction and biosynthesis of the transporter ceases. 5-HT transporter immunoreactivity was strikingly marginal in individual cells, consistent with a concentration of the transporter in the plasma membrane. Few of the 5-HT-containing EC cells expressed 5-HT transporter immunoreactivity, accounting for the failure of these cells to become labeled by ${ }^{3} \mathrm{H}-5-\mathrm{HT}$. The expression of the $5-\mathrm{HT}$ transporter in the epithelium, therefore, differs from its expression in the ENS and CNS, where the cells that secrete 5-HT are the cells that also express the 5-HT transporter. Epithelial expression of the transporter is thus a capture and not a recapture mechanism.

Our observations are consistent with the idea that the peristaltic reflex is evoked by the release of 5-HT from mucosal EC cells to stimulate intrinsic sensory nerves. The current observations represent the first report of an inactivating mechanism for 5-HT in the mucosa and thus provide support for the hypothesis that the mucosal action of 5-HT is important in neurally mediated reflexes in the gut.

\section{REFERENCES}

Ahlman H, Bhargava N, Donahue PE, Newson B, Das Gupta TK, Nyhus $M$ (1978) The vagal release of 5-hydroxytryptamine from enterochromaffin cells in the cat. Acta Physiol Scand 104:262-270.

Ahlman H, Bhargava HN, Dahlström A, Larsson I, Newson B, Pettersson $\mathrm{G}$ (1981a) On the presence of serotonin in the gut lumen and possible release mechanisms. Acta Physiol Scand 112:263-269.

Ahlman H, DeMagistris L, Zinner MJ, Jaffe BM (1981b) Release of immunoreactive serotonin into the lumen of the feline gut in response to vagal nerve stimulation. Science 213:254-255.

Baldessarini RJ (1990) Drugs and the treatment of psychiatric disorders. In: The pharmacological basis of therapeutics (Gilman AG, Rall TW, Nies AS, Taylor P, eds), pp 383-435. New York: Pergamon.

Blakely RD, Berson HE, Fremeau RT, Caron MG, Peek MM, Prince HK, Bradley CC (1991) Cloning and expression of a functional serotonin transporter from rat brain. Nature 354:66-70.

Blakely RD, Moore KR, Qian Y (1993) Tails of serotonin and norepinephrine transporters: deletions and chimeras retain function. In: Molecular biology and function of carrier proteins (Reuss L, Russell Jr JM, Jennings ML, eds), pp 284-300. New York: Rockefeller UP.

Branchek T, Rothman T, Gershon MD (1984a) Serotonin receptors on the processes of intrinsic enteric neurons: reduction in the aganglionic bowel of the 1s/ls mouse. Soc Neurosci Abstr 10:1097.

Branchek TA, Kates M, Gershon MD (1984b) Enteric receptors for 5-hydroxytryptamine. Brain Res 324:107-118.

Brownstein MJ, Hoffman BJ (1994) Neurotransmitter transporters. In: Recent progress in hormone research, Vol 49 (Bardin CW, ed), pp 27-42. San Dicgo: Academic.

Bülbring E, Crema A (1959a) The action of 5-hydroxytryptamine, 5-hydroxytryptophan and reserpine on intestinal peristalsis in anaesthetized guinea-pigs. J Physiol (Lond) 146:29-53.

Bulbring E, Crema A (1959b) The release of 5-hydroxytryptamine in relation to pressure exerted on the intestinal mucosa. $\mathbf{J}$ Physiol (Lond) $146: 18-28$

Bülbring E, Lin RCY (1958) The effect of intraluminal application of 5-hydroxytryptamine and 5-hydroxytryptophan on peristalsis, the local production of 5-hydroxytryptamine and its release in relation to intraluminal pressure and propulsive activity. J Physiol 140:381-407.
Bülbring E, Lin RCY, Schofield G (1958) An investigation of the peristaltic reflex in relation to anatomical observations. Q J Exp Physiol 43:26-37.

Burnstock G (1983) Recent concepts of chemical communication between excitable cells. In: Dale's principle and communication between neurones (Osborne NN, ed), pp 7-35. New York: Pergamon.

Chomczynski P, Sacchi N (1987) Single-step method of RNA isolation by acid guanidinium thiocyanate-phenol-chloroform extraction. Anal Biochem 162:156-159.

Cooke HJ, Montakhab M, Wade PR, Wood JD (1983) Transmural fluxes of 5-hydroxytryptamine in guinea pig ileum. Am J Physio 244:G421-G425.

Cooke HJ, Reddix RA (1994) Neural regulation of intestinal electrolyte transport. In: Physiology of the gastrointestinal tract 2 (Johnson LR, Alpers DH, Christensen J, Jacobson ED, Walsh JH, eds), pp 20832132. New York: Raven

Costa M, Furness JB (1976) The peristaltic reflex: an analysis of the nerve pathways and their pharmacology. Naunyn Schmiedebergs Arch Pharmacol 294:47-60.

Costa M, Furness JB, Cuello AC, Verhofstad AAJ, Steinbusch HWJ, Elde RP (1982) Neurons with 5-hydroxytryptamine-like immunoreactivity in the enteric nervous system: their visualization and reactions to drug treatment. Neuroscience 7:351-363.

Erde SM, Sherman D, Gershon MD (1985) Morphology and serotonergic innervation of physiologically identified cells of the guinea pig's myenteric plexus. J Neurosci 5:617-633.

Erspamer V (1954) Quantitative estimation of 5-HT in gastrointestinal tract, spleen and blood of vertebrates. In: CIBA Symposium on Hypertension (Wolstenholme G, Cameron MP, eds), pp 78-84. London: Churchill.

Feldberg W, Toh CC (1953) Distribution of 5-hydroxytryptamine (serotonin, enteramine) in the wall of the digestive tract. J Physiol (Lond) 119:352-362

Feng T, McCallum RW, Smith TK (1994) Asymmetry in contractile responses of the circular muscle during peristalsis to serotonin in the guinea-pig ileum (Abstr). Gastroenterology 106:497A.

Foxx-Orenstein AE, Kuemmerle JF, Grider JR (1995) The peristaltic reflex induced by mucosal stimuli in human and guinea pig intestine is mediated by distinct mucosal 5-HT receptors (Abstr). Gastroenterology 108:A600.

Furness JB, Costa M (1982) Neurons with 5-hydroxytryptamine-like immunoreactivity in the enteric nervous system: their projections in the guinea pig small intestine. Neuroscience 7:341-350.

Furness JB, Johnson PJ, Pompolo S, Bornstein JC (1995) Evidence that enteric motility reflexes can be initiated through entirely intrinsic mechanisms in the guinea-pig small intestine. Neurogastroenterol Mot 7:89-96.

Gershon MD, Jonakait GM (1979) Uptake and release of 5-hydroxytryptamine by enteric serotonergic neurons: effects of fluoxetine (Lilly 110140) and chlorimipramine. Br J Pharmacol 66:7-9.

Gershon MD, Ross LL (1966) Location of sites of 5-hydroxytryptamine storage and metabolism by radioautography. J Physiol (Lond) 186:477-492.

Gershon MD, Sherman DL (1982) Identification of and interactions between noradrenergic and serotonergic neurites in the myenteric plexus. J Comp Neurol 204:407-421.

Gershon MD, Sherman DL (1987) Noradrenergic innervation of serotonergic neurons in the myenteric plexus. J Comp Neurol 259:193-210.

Gershon MD, Tamir H (1981) Release of endogenous 5-hydroxytryptamine from resting and stimulated enteric neurons. Neuroscience 6:2277-2286.

Gershon MD, Wade PR (1994) New developments in the enteric nervous system. Curr Opin Gastroenterol 10:183-192.

Gershon MD, Kirchgessner AL, Wade PR (1994) Functional anatomy of the enteric nervous system. In: Physiology of the gastrointestinal tract 1 (Johnson LR, Alpers DH, Christensen J, Jacobson ED, Walsh JH, eds), pp 381-422. New York: Raven.

Gershon MD, Robinson R, Ross LL (1976) Serotonin accumulation in the guinea pig's myenteric plexus: ion dependence, structure activity relationship and the effect of drugs. J Pharmacol Exp Ther 198:548-561.

Gershon MD, Sherman DL, Pintar JE (1990) Type-specific localization of monoamine oxidase in the enteric nervous system: relationship to 5-hydroxytryptamine, neuropeptides, and sympathetic nerves. J Comp Neurol 301:191-213. 
Gordon JI, Schmidt GH, Roth KA (1992) Studies of intestinal stem cells using normal, chimeric, and transgenic mice. FASEB J 6:3039-3050.

Grider JR (1994) CGRP as a transmitter in the sensory pathway mediating peristaltic reflex. Am J Physiol 266:G1139-G1145.

Grider JR, Jin J-G (1994) Distinct populations of sensory neurons mediate the peristaltic reflex elicited by muscle stretch and mucosal stimulation. J Neurosci 14:2854-2860.

Grider JR, Kuemmerle JF, Jin J-G (1994) 5-HT released by mucosal stimulation acts via $5-\mathrm{HT}_{4}$ receptors to release the sensory transmitter CGRP and initiate the peristaltic reflex (Abstr). Gastroenterology 106:506A.

Harland RM (1991) In situ hybridization: an improved whole Inount method for Xenopus embryos. In: Methods in cell biology 36 (Kay BK, Peng HJ, eds), pp 675-685. New York: Academic.

Hoffman B, Mezey E, Brownstein M (1991) Cloning of a serotonin transporter affected by antidepressants. Science 254:579-580.

Kadowaki M, Nagakura Y, Fushimi M, Tomoi M, Mori J, Kohsaka M (1993) Combined antagonism of $5-\mathrm{HT}_{3}$ and $5-\mathrm{HT}_{4}$ receptors by FK1052 and SDZ205-557 inhibits motility in the rat colon (Abstr). Gastroenterology 104:1297A.

Kirchgessner AL, Mawe GM, Gershon MD (1990) Evaluation of the activity of chemically identified enteric neurons through the histochemical detection of cytochrome oxidase. J Comp Neurol 301:1 14.

Kirchgessner AL, Tamir H, Gershon MD (1992) Identification and stimulation by serotonin of intrinsic sensory neurons of the submucosal plexus of the guinea pig gut: activity-induced expression of Fos immunoreactivity. J Neurosci 12:235-248.

Kosterlitz HW, Lees GM (1964) Pharmacological analysis of intrinsic intestinal reflexes. Pharmacol Rev 16:301-339.

Nilsson O, Ahlman H, Geffard M, Dahlström A, Ericson LE (1987) Bipolarity of duodenal enterochromaffin cells in the rat. Cell Tissue Res 248:49-54.

Penttilä A (1967) 5-hydroxytryptamine in the enterochromaffin cells of the guinea pig alimentary tract. Histochemie 11:185-194.
Qian Y, Melikian HE, Rye DB, Levey AI, Blakely RD (1995) Identification and characterization of antidepressant-sensitive serotonin transporter proteins using site-specific antibodies. J Neurosci 15:1261-1274.

Rudnick G (1977) Active transport of 5-hydroxytryptamine by plasma membrane vesicles isolated from human blood platelets. J Biol Chem 252:2170-2174.

Smith TK, Bornstein JC, Furness JB (1990) Distension-evoked ascending and descending reflexes in the circular muscle of the guinea-pig ilcum: an intracellular study. J Auton Nerv Syst 29:203-218.

Takaki M, Mawe GM, Barasch J, Gershon MD (1985) Physiological responses of guinea-pig myenteric neurons secondary to the release of endogenous serotonin by tryptamine. Neuroscience 16:223-240.

Ternaux JP, Gonella J, Legay C, Faudon M, Barrit MC, Héry F (1981) 5-H'I metabolism in the intestinal wall of the rabbit. J Physiol (Paris) 77:319-326.

Thompson JH, Campbell LB (1967) The distribution of argentaffin cells in the gastrointestinal tract of the sulfamerazine treated rat. Experientia 23:825-826.

Toh CC (1954) Release of 5-hydroxytryptamine (serotonin) from the dog's gastrointestinal tract. J Physiol (Lond) 126:248-254.

Trendelenburg P (1917) Physiologische und pharmakologische Versuche über die Dünndarm Peristaltick. Naunyn Schmicdebergs Arch Exp Pathol Pharmakol 81:55-129.

Tutton PJM (1974) The influence of serotonin on crypt cell proliferation in the jejunum of rat. Virchows Arch B Cell Pathol 16:79-87.

Wade PR, Tamir H, Kirchgessner AL, Gershon MD (1994) Analysis of the role of 5-HT in the enteric nervous system using anti-idiotypic antibodies to 5-HT receptors. Am J Physiol 266:G403-G416.

Welsh MJ, Smith PL, Fromm M, Frizzell RA (1982) Crypts are the site of intestinal fluid and electrolyte secretion. Science 218:1219-1221.

Williams DC, Phillips OM (1991) Probing the platelet plasma-membrane 5-hydroxytryptamine transporter. Biochem Soc Trans 19:112-114. 